\title{
Generation and Analysis of GluR5(Q636R) Kainate Receptor Mutant Mice
}

\author{
Andreas Sailer, ${ }^{1}$ Geoffrey T. Swanson, ${ }^{1}$ Isabel Pérez-Otaño, ${ }^{1}$ Lora O’Leary, ${ }^{1}$ Shelle A. Malkmus, ${ }^{4}$ \\ Richard H. Dyck, ${ }^{1}$ Heather Dickinson-Anson, ${ }^{3}$ Hans H. Schiffer, ${ }^{1}$ Cornelia Maron, ${ }^{1}$ Tony L. Yaksh, ${ }^{4}$ \\ Fred H. Gage, ${ }^{3}$ Stephen O'Gorman, ${ }^{2}$ and Stephen F. Heinemann ${ }^{1}$ \\ ${ }^{1}$ Molecular Neurobiology Laboratory, ${ }^{2}$ Gene Expression Laboratory, and ${ }^{3}$ Laboratory of Genetics, The Salk Institute for \\ Biological Studies, La Jolla, California 92037, and ${ }^{4}$ Department of Pharmacology and Anesthesiology, University of \\ California, San Diego, La Jolla, California 92093
}

The physiological significance of RNA editing of transcripts that code for kainate-preferring glutamate receptor subunits is unknown, despite the fact that the functional consequences of this molecular modification have been well characterized in cloned receptor subunits. RNA editing of the codon that encodes the glutamine/arginine $(\mathrm{Q} / \mathrm{R})$ site in the second membrane domain (MD2) of glutamate receptor 5 (GluR5) and GluR6 kainate receptor subunits produces receptors with reduced calcium permeabilities and single-channel conductances. Approximately $50 \%$ of the GluR5 subunit transcripts from adult rat brain are edited at the $\mathrm{Q} / \mathrm{R}$ site in MD2. To address the role of glutamate receptor $\mathrm{mRNA}$ editing in the brain, we have made two strains of mice with mutations at amino acid 636 , the Q/R-editing site in GluR5, using embryonic stem cell-mediated transgenesis. GluR5( $\left.R^{\text {loxP }} / R^{\text {loxP }}\right)$ mice encode an arginine at the Q/R site of the GluR5 subunit, whereas GluR5(wt ${ }^{\text {loxP }} /$ wt $^{\text {loxP }}$ ) mice encode a glutamine at this site, similar to wild-type mice. Mutant animals do not exhibit developmental abnormalities, nor do they show deficits in the behavioral paradigms tested in this study. Kainate receptor current densities were reduced by a factor of six in acutely isolated sensory neurons of dorsal root ganglia from GluR5( $\left.R^{\text {loxP }} / R^{\text {loxP }}\right)$ mice compared with neurons from wild-type mice. However, the editing mutant mice did not exhibit altered responses to thermal and chemical pain stimuli. Our investigations with the GluR5-editing mutant mice have therefore defined a set of physiological processes in which editing of the GluR5 subunit is unlikely to play an important role.

Key words: RNA editing; glutamate receptor; pain; dorsal root ganglia; gene targeting; Cre recombinase
Ionotropic receptors activated by the major excitatory neurotransmitter in the mammalian CNS, L-glutamate, are formed from three gene families: AMPA receptors, kainate receptors, and NMDA receptors (for review, see Dingledine et al., 1999). Whereas the role of AMPA and NMDA in synaptic transmission has been established, the role of kainate receptors in the nervous system has been less clear because of a lack of pharmacological tools. The recent development of selective agonists and antagonists (Paternain et al., 1995; Bleakman et al., 1996; Wilding and Huettner, 1997) as well as the application of mouse genetics (Mulle et al., 1998) has demonstrated that kainate receptors participate in synaptic transmission in the peripheral $(\mathrm{Li}$ et al.,

Received June 16, 1999; revised Aug. 2, 1999; accepted Aug. 2, 1999.

This work was supported by grants and fellowships of the Schweizerische Nationalfond and the Deutsche Forschungsgemeinschaft to A.S., a National Research Service Award fellowship to G.T.S., the Spanish Ministerio de Educación y Ciencia to I.P.-O., a joint program project grant to F.H.G. and S.F.H. (National Institutes of Health/National Institute on Aging), and grants of the National Institutes of Health (National Institute of Neurological Disorders and Stroke) and the McKnight foundation to S.F.H. The excellent technical assistance of Y. Marchuk, N. Dagenais, H. Garjeda, and the animal research departments is gratef ully acknowledged. Genomic clones of GluR5 were generously provided by B. Bettler and C. Mulle, and CCE ES cells were donated by E. Robertson. We thank A. Contractor for comments on this manuscript.

Correspondence should be addressed to Dr. Geoffrey T. Swanson, Molecular Neurobiology Laboratory, The Salk Institute for Biological Studies, La Jolla, CA 92037.

Dr. Andreas Sailer's present address: Merck and Company, Inc., P.O. Box 2000, RY80M-213, Rahway, NJ 07065.

Dr. Richard H. Dyck's present address: University of Calgary, 2500 University Drive, Northwest, Calgary, Alberta, Canada.

Copyright (C) 1999 Society for Neuroscience $0270-6474 / 99 / 198757-08 \$ 05.00 / 0$
1999) and CNS (Castillo et al., 1997; Clarke et al., 1997; Rodriguez-Moreno et al., 1997; Vignes and Collingridge, 1997; Cossart et al., 1998; Frerking et al., 1998).

Critical channel properties of kainate and AMPA receptors are determined by the glutamine/arginine $(\mathrm{Q} / \mathrm{R})$ site residue [amino acid 636 in the glutamate receptor 5 (GluR5) subunit] in the second membrane domain (MD2) of the subunit protein (for review, see Dingledine et al., 1999). Receptors formed from subunits with a glutamine at this site are more calcium permeable and have a higher single-channel conductance than do those composed of arginine-containing subunits. GluR2 AMPA receptor subunit cDNAs were found to encode an arginine at this site (Boulter et al., 1990; Keinänen et al., 1990; Nakanishi et al., 1990), but surprisingly a glutamine was found to be encoded in the gene (Sommer et al., 1991). The arginine codon is introduced into the precursor RNA by an enzymatic-editing event that converts an adenosine to an inosine; the inosine is subsequently read as a guanosine, resulting in the change in codon identity (Sommer et al., 1991; Higuchi et al., 1993). Essentially all mRNA transcripts for GluR2 are edited in adult rat brain (Sommer et al., 1991). In contrast, at the analogous site in GluR5 and GluR6, RNA editing is incomplete $[\sim 50 \%$ of GluR5 and $75 \%$ of GluR6 adult rat brain mRNA (Sommer et al., 1991; Egebjerg and Heinemann, 1993; Köhler et al., 1993; Bernard et al., 1999)]. The extent of GluR5 $\mathrm{Q} / \mathrm{R}$ site editing increases from very low levels in embryonic brain to $\sim 50 \%$ within a few days after birth (Bernard et al., 1999), suggesting that the process is under tight regulatory control. The significance of this switch in receptor mRNA isoforms, which will 
Figure 1. Generation of GluR5(Q636R) mutant mice. A, Genomic map of the GluR5 locus around the exon coding for the MD2 domain is shown. $B$, The targeting vectors contained either the point mutation ( $\mathrm{CGG}=\mathrm{R}$ form, $\mathrm{pR} 5 \mathrm{G} 57 \mathrm{R})$ or the wild-type sequence (CAG $=\mathrm{Q}$ form, pR5G57Q) at the Q/R site. A loxP-flanked neomycin resistance marker (neo) was inserted $\sim 0.8 \mathrm{~kb} \mathrm{3}{ }^{\prime}$ of the $\mathrm{Q} / \mathrm{R}$ site. The hatched horizontal bar labeled PGK-TK denotes the phosphoglycerate-kinase-thymidine kinase domain of the targeting vector. $C$, An illustration of the GluR5 locus after homologous recombination of the targeting vectors $(\mathrm{R}$ or $\mathrm{Q}$ form) and excision of the neomycin resistance marker using Cre recombinase is shown. Abbreviations for restriction sites are as follows: $E, E c o$ RI; $S, S p e I ; X, X h o I$; and $X b$, $X b a \mathrm{I}$. $D, E$, Southern blot hybridization analysis of mouse genomic tail DNA from wild-type (wt/wt), heterozygous (wt/ $\left.\mathrm{R}^{\operatorname{lox} P}\right)$, homozygous mutant $\left(\mathrm{R}^{\operatorname{loxP}} / \mathrm{R}^{\text {loxP }}\right)$, and homozygous control ( $\left.\mathrm{wt}^{\mathrm{loxP}} / \mathrm{wt}^{\mathrm{loxP}}\right)$ mice using probe $A$ on SpeI-digested DNA $(D)$ and probe $B$ on EcoRI-digested DNA $(E)$ is shown (location of the probe sequences indicated by gray horizontal bars in $A$ ).
A

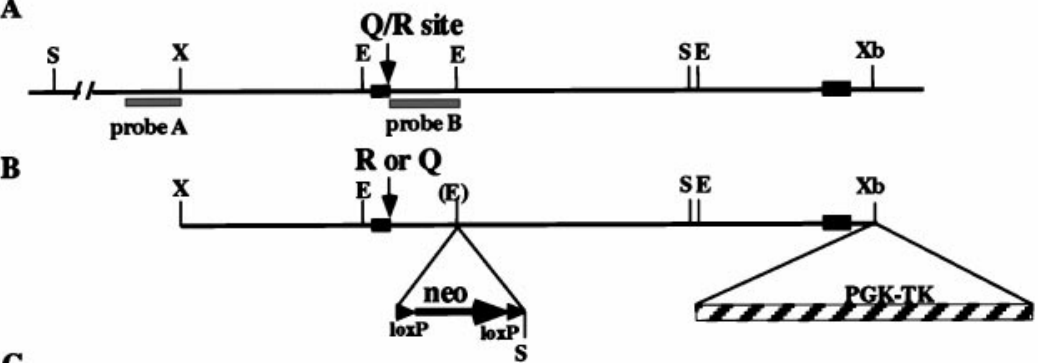

$\mathbf{C}$

D

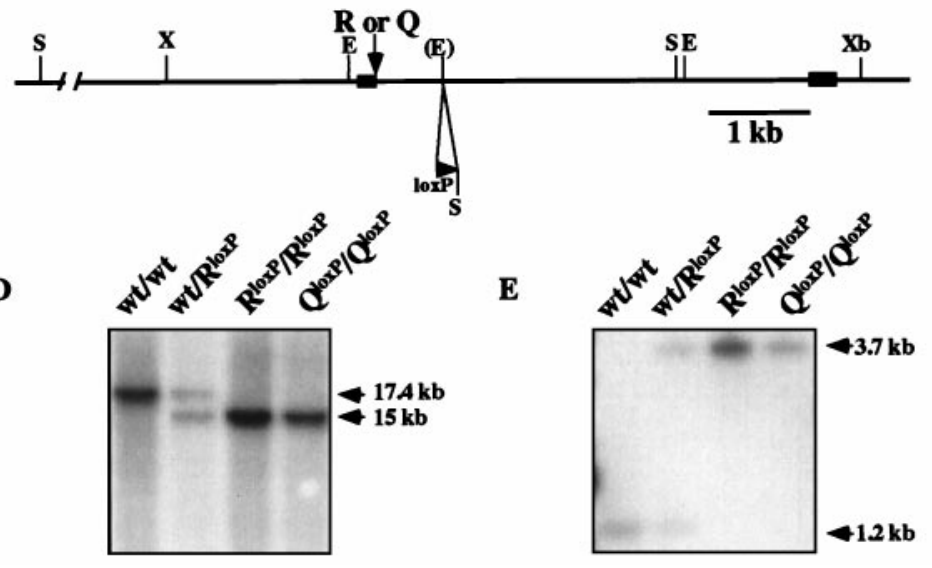

consequently alter the functional properties of the kainate receptors formed from these subunits, remains unclear, as does the importance of analogous $\mathrm{Q} / \mathrm{R}$ site editing of the GluR6 kainate receptor subunit mRNA.

One way of exploring the significance of mRNA editing of kainate receptor subunits is to alter the extent of editing in mice using transgenic techniques. We have used genetic manipulations to investigate the physiological and behavioral consequences of expression of solely calcium-impermeable GluR5 kainate receptor subunits. We describe in this report the techniques used for generating the mutant mice, as well as phenotypic characterization of their behavior and physiology.

\section{MATERIALS AND METHODS}

Construction of the targeting vectors $p R 5 G 57 R$ and $p R 5 G 57 Q$. Subclones containing genomic fragments from the mouse 129Sv GluR5 locus were used as templates for site mutagenesis reactions that introduced an adenine to guanine mutation in the $\mathrm{Q} / \mathrm{R}$ site codon. The genomic DNAs were kindly provided by B. Bettler (Novartis, Basel, Switzerland) and C. Mulle (University of Bordeaux, Bordeaux, France). The point mutation at the $\mathrm{Q} / \mathrm{R}$ site that alters the $\mathrm{CAG}(\mathrm{Q})$ to $\mathrm{CGG}(\mathrm{R})$ in the exon coding for MD2 was introduced using PCR primer-mediated mutagenesis, with primers R5sac and E3Xma (see below), from a SacI site in the MD2 exon to an intronic Eco RI site located $\sim 0.8 \mathrm{~kb}$ downstream of the Q/R-editing site. In parallel, a PCR reaction using a $5^{\prime}$ primer (Q5sac) with the wild-type sequence was performed. The $5^{\prime}$ primers were R5sac (5'GTTGGAGCTCTCATGCGGCAAGGTACACCG) and Q5sac (5'GTTGGAGCTCTCATGCAGCAAGGTACACCG). The 3' primer was E3Xma (5'-TCCCCCCGGGCCAACTTCCAAGGATTT). The PCR protocol had the following parameters: 1 cycle of $95^{\circ} \mathrm{C}$ for $5 \mathrm{~min} ; 30$ cycles of $65^{\circ} \mathrm{C}$ for $45 \mathrm{sec}, 72^{\circ} \mathrm{C}$ for $1.5 \mathrm{~min}$, and $92^{\circ} \mathrm{C}$ for $45 \mathrm{sec}$; and 1 cycle of $72^{\circ} \mathrm{C}$ for $5 \mathrm{~min}$. The final targeting constructs contained 3.1 and $4.1 \mathrm{~kb}$ of homologous sequence $5^{\prime}$ and $3^{\prime}$, respectively, to the loxP-flanked neomycin resistance marker. In the case of the targeting vector pR5G57R, the $5^{\prime}$ homologous sequence was interrupted by the Q/R site point mutation, resulting in $2.3 \mathrm{~kb}$ of $5^{\prime}$ homologous sequence. In addition, the targeting vectors also contained a thymidine kinase (TK) gene under the control of the phosphoglycerate-kinase (PGK) promoter (Fig. 1B) (Mansour et al., 1988). Before transfection of embryonic stem cells, the targeting vectors were linearized by $\mathrm{XhoI}$ digestion.
Embryonic stem cell technology and Cre recombinase. CCE embryonic stem (ES) cells were cultured as described (Robertson, 1987). Electroporation with targeting vectors or a Cre-expressing plasmid, pOG231, was done as detailed previously (O'Gorman et al., 1997). With the targeting vectors we found 9 of 314 clones positive for homologous recombination. Six of those clones were thawed and electroporated with the pOG231 DNA. A total of 546 individual colonies were subjected to PCR analysis with primers flanking the neomycin gene [primers, R5SP1 (5'-TTTTCCTTCTTAGCCATAACTTCACAAGTC) and R5SP2 (5'CTCCACAAACAAAAGCAAAAATCTCTGAAAT)]. The PCR parameters were the following: 1 cycle at $94^{\circ} \mathrm{C}$ for $4 \mathrm{~min} ; 30$ cycles at $65^{\circ} \mathrm{C}$ for $45 \mathrm{sec}, 72^{\circ} \mathrm{C}$ for $45 \mathrm{sec}$, and $92^{\circ} \mathrm{C}$ for $15 \mathrm{sec}$; and $1 \mathrm{cycle}$ at $72^{\circ} \mathrm{C}$ for 5 min. The expected length of the PCR products was $307 \mathrm{bp}$ for the wild-type allele and 392 bp for the Cre-recombined allele. We found a total of 75 clones that showed detectable levels of Cre recombination. Clones that did not show detectable levels of the neomycin-containing allele in a Southern blot were chosen for blastocyst injection. Chimeric mice from four different clones transmitted the mutant allele to their offspring as judged by Southern blot analysis of the GluR5 genomic locus (Laird et al., 1991) (Fig. 1D,E, probes $A, B$ ). Animals derived from clones R23\#362 and Q9\#37 were used for subsequent analysis.

Editing assay on genomic DNA and total brain RNA. Genomic DNA was isolated using an isopropanol precipitation protocol (Laird et al., 1991) and subsequently was purified by phenol-chloroform extraction. The isolated DNA was used as a template in a PCR reaction to amplify the $645 \mathrm{bp}$ sequence surrounding the $\mathrm{Q} / \mathrm{R}$-editing site. The sense and antisense primers we used were R5SP3 and R5SP4 and had the sequences 5'-GCATTTAGTCCCACAGAGCTGAAAGAGG and 5'-TGTCACT TGCCCCAATCTCCTGTTGCC, respectively. The PCR protocol was 1 cycle at $94^{\circ} \mathrm{C}$ for $5 \mathrm{~min} ; 37 \mathrm{cycles}$ at $57^{\circ} \mathrm{C}$ for $60 \mathrm{sec}, 72^{\circ} \mathrm{C}$ for $45 \mathrm{sec}$, and $92^{\circ} \mathrm{C}$ for $20 \mathrm{sec}$; and 1 cycle at $72^{\circ} \mathrm{C}$ for $5 \mathrm{~min}$. Rat brain total RNA was isolated (Chomczynski and Sacchi, 1987), and random-primed firststrand synthesis was performed using the Superscript kit (Life Technologies, Gaithersburg, MD) according to the manufacturer's protocol. Using this cDNA as template in a PCR reaction, we amplified and isolated a $610 \mathrm{bp}$ fragment using the following protocol: the sense primer R5SP8 was 5'-GGGAGTGGAACGGGATGGTTAAG, the antisense primer R5.2623 was 5'-AGGTCATTGTCGAGCCATCTCTG, and the PCR protocol was that described for the genomic DNA, with the exception that the annealing was performed at $60^{\circ} \mathrm{C}$.

Editing assays were performed by first mixing PCR fragments with a ${ }^{32} \mathrm{P}$-labeled oligonucleotide, 5'-TGGCGTTGGAGCTCTCA (R5SP5), 
which was complementary to a sequence immediately upstream of the editing site. The primer was then extended in the presence of ddATP using thermostable Sequenase polymerase (Amersham, Arlington Heights, IL) in a cycled reaction (parameters, $90^{\circ} \mathrm{C}$ for $10 \mathrm{sec} ; 50^{\circ} \mathrm{C}$ for 30 $\mathrm{sec} ; 72^{\circ} \mathrm{C}$ for $10 \mathrm{sec}$; five cycles). Extended primers were separated on a denaturing polyacrylamide gel with electrophoresis. Quantification was performed using a phosphorimager using the software ImageQuant NT (Molecular Dynamics, Sunnyvale, CA).

In situ hybridization. Mutant and wild-type mice were anesthetized with sodium pentobarbital (Nembutal; $40 \mathrm{mg} / \mathrm{kg}$, i.p.) and perfused transcardially with $4 \%$ paraformaldehyde in $0.1 \mathrm{M} \mathrm{PBS,} \mathrm{pH} 7.4-7.6$. The brain was removed, mounted in tissue-freezing medium at $-54^{\circ} \mathrm{C}$, and brought to $-23^{\circ} \mathrm{C}$. Transversal sections were cut at $16 \mu \mathrm{m}$ in a cryostat. In situ hybridization was performed following the protocol described by Simmons et al. (1989). Slides were hybridized at $55^{\circ} \mathrm{C}$ for $12-16 \mathrm{hr}$ with ${ }^{33} \mathrm{P}$-labeled sense and antisense RNA probes [rat GluR5 $5^{\prime}$ probe nucleotides 1223-1879 and mouse GluR5 $3^{\prime}$ probe nucleotides 2730-3377 (Gregor et al., 1993; Bischoff et al., 1997)]. Sense probes served as specificity controls. After hybridization, ribonuclease treatment, and high-stringency washes, the slides were exposed to autoradiographic emulsion (NTB2; Eastman Kodak, Rochester, NY) for 10-14 d. After development of the emulsion, sections were counterstained using toluidine blue, dehydrated, and mounted.

Histochemistry. Two methods were used to compare the barrel patterning in mutant and wild-type mice. The procedures used to visualize synaptic zinc, which is found in the axon terminals of a subset of glutamatergic neurons in the mammalian neocortex, have been detailed previously (Dyck et al., 1993) and are based on a variation of the Timm stain (Danscher, 1982). The topographic distribution of zinc was compared, in adjacent sections, with that of cytochrome oxidase (CO) that was visualized histochemically using a modification of the method described by Silverman and Tootell (1987). Before staining, slide-mounted sections were fixed for $5 \mathrm{~min}$ in $4 \%$ paraformaldehyde in $50 \mathrm{~mm}$ phosphate buffer (PB), $\mathrm{pH}$ 7.4. Sections were rinsed twice for $5 \mathrm{~min}$ in $\mathrm{PB}$ and then incubated at $37^{\circ} \mathrm{C}$ for $45-60 \mathrm{~min}$ in a solution consisting of $50 \mathrm{mg}$ of nickel ammonium sulfate, $250 \mu \mathrm{l}$ of $1 \mathrm{M}$ imidazole, $1 \mathrm{gm}$ of sucrose, $25 \mathrm{mg}$ of 3, 3'-diaminobenzidine tetrahydrochloride, $15 \mathrm{mg}$ of cytochrome $\mathrm{C}$, and $10 \mathrm{mg}$ of catalase in $100 \mathrm{ml}$ of PB. After incubation, the slides were rinsed in buffer, dehydrated in an ascending series of alcohols, cleared in xylene, and coverslipped using Permount.

Behavior. All mice [GluR5( $\left.\mathrm{wt}^{\text {loxP}} / \mathrm{wt}^{\text {loxP }}\right)(n=20)$; GluR5( $\mathrm{R}^{\text {loxP }} /$ $\left.\mathrm{R}^{\operatorname{loxP}}\right)(n=27)$ ] used were 4 - to 12 -month-old male C57BL/6x129Sv hybrids. All behavioral testing and data collection were conducted by an investigator blinded to the genotype of the mice. Rotarod motor learning and locomotor activity were performed as described (Mulle et al., 1998). The hidden platform water maze test was performed as described (Kempermann et al., 1997).

Kainate injection. C57BL/6x129Sv hybrid mice $\left[\mathrm{GluR} 5\left(\mathrm{R}^{\operatorname{lox} \mathrm{P}} / \mathrm{R}^{\operatorname{loxP}}\right)\right.$ $(n=15)$; GluR5(wt $\left.{ }^{\text {loxP}} / \mathrm{wt}^{\text {loxP }}\right)(n=12)$; GluR5(wt/wt $\left.)(n=10)\right]$ used were $13-15$ months old. After intraperitoneal administration of $20 \mathrm{mg} / \mathrm{kg}$ kainic acid, mice were monitored continuously for $2 \mathrm{hr}$ for the onset and extent of seizures (see Mulle et al., 1998). Seizure severity was rated according to a defined scale: $0=$ no seizure, $1=1$ seizure, $2=2-5$ seizures, $3=6-10$ seizures, $4=>10$ or severe tonic-clonic seizure, and $5=$ death within $2 \mathrm{hr}$. A seizure index was calculated by averaging the points for seizure severity in a given group.

Preparation of dorsal root ganglia neurons. Mice between the ages of postnatal day 1 (P1) and P8 were rapidly decapitated, and the spines were transferred to $10 \mathrm{~mm}$ HEPES-buffered saline solution. Dorsal root ganglia (DRG) were removed after bisection of the spinal column and removal of the spinal cord. Ganglia were incubated in 20 units $/ \mathrm{ml}$ papain in HEPES-buffered saline solution with $1 \mathrm{mM} \mathrm{CaCl}_{2}$ and $0.5 \mathrm{~mm}$ EDTA, triturated, and washed with DMEM and $10 \%$ fetal calf serum (Life Technologies). Dissociated neurons were plated on poly-D-lysine and/or collagen-coated glass coverslips and allowed to recover for 4-6 hr in a $37^{\circ} \mathrm{C}$ incubator with $5 \% \mathrm{CO}_{2}$.

Electrophysiology. Patch-clamp recordings were made as described previously (Swanson and Heinemann, 1998) using an Axopatch 200B amplifier (Axon Instruments, Foster City, CA). The internal solution was composed of $110 \mathrm{~mm} \mathrm{CsF}, 30 \mathrm{~mm} \mathrm{CsCl}, 4 \mathrm{~mm} \mathrm{NaCl}, 0.5 \mathrm{~mm} \mathrm{CaCl}_{2}, 10$ $\mathrm{mM}$ HEPES, and $5 \mathrm{~mm}$ EGTA (adjusted to $\mathrm{pH} 7.3$ with $\mathrm{CsOH}$ ). The external bath solution contained $150 \mathrm{~mm} \mathrm{NaCl}, 2.8 \mathrm{~mm} \mathrm{KCl}, 1.8 \mathrm{~mm}$ $\mathrm{CaCl}_{2}, 1.0 \mathrm{~mm} \mathrm{MgCl}_{2}$, and $10 \mathrm{~mm}$ HEPES ( $\mathrm{pH}$ was adjusted to 7.3 with $\mathrm{NaOH})$. Data were acquired directly to a computer and were analyzed off-line using pClamp software (Axon Instruments). To determine cell capacitance, we applied $5010 \mathrm{mV}$ voltage steps to the cell, and the current responses were averaged. The time constant of the current decay was used to calculate the membrane capacitance. Exponential decays were fitted with the Chebyshev or Simplex least-squares algorithms in Clampfit.

Pain tests. For analysis of acute thermal nociception, animals were placed on a heated surface $\left(52.5^{\circ} \mathrm{C}\right)$, and latency to jump or vocalization was recorded (Hayes et al., 1987; Gaumann et al., 1989). In the formalin tests, mice were placed on wood shavings bedding in a clear Plexiglas box measuring $22 \times 8 \mathrm{~cm}$. Mice were individually acclimated to the chamber for a minimum of $30 \mathrm{~min}$ before the experiment. Formalin (5\% solution) was injected subcutaneously in the dorsum of the left hindpaw, and observations of paw licking and biting behavior were started immediately. The licking and biting behavior of the injected paw was recorded in seconds for intervals of $5 \mathrm{~min}$, up to $45 \mathrm{~min}$. A mirror placed at the back of the box allowed unhindered observation of the formalin-injected paw. Animals were killed immediately after the testing period (Hunskaar et al., 1985).

\section{RESULTS}

\section{Generation of GluR5(Q636R) mutant mice}

We generated mice that expressed GluR5 kainate receptor subunits that were completely edited at the Q/R site in MD2 using gene-targeting technology. For this purpose we constructed two targeting vectors for homologous integration into the GluR5 locus (Fig. 1 $A, B$ ). One targeting vector, pR5G57R, carried an arginine-encoding point mutation at the $\mathrm{Q} / \mathrm{R}$ site codon (CGG), and the other, pR5G57Q, contained the wild-type sequence at the same site (CAG). Both targeting vectors contained a neomycin resistance marker flanked by loxP recognition sequences and a TK gene under the control of the PGK promoter (as illustrated in Fig. 1B). CCE embryonic stem cells were electroporated with both targeting constructs (Robertson et al., 1986). Southern analysis of neomycin-resistant clones from both transfections revealed that a total of 9 of 314 ES cell clones had the GluR5 genome structure predicted to result from homologous recombination of the targeting vectors (data not shown). To excise the neomycin gene from the GluR5 intronic sequence, six of the nine positive clones from the first screening (three "R" clones and three "Q" clones) were transfected with a Cre recombinase expression plasmid [pOG231 (O'Gorman et al., 1997)]. After plating under nonselective conditions, individual clones that did not contain the neomycin marker were identified using PCR assays and Southern blotting (see Fig. $1 C$ for illustration of the mutant allele after removal of the neomycin marker; screening data not shown). Subsequently, the selected clones were injected into blastocysts to generate chimeric animals, which after breeding with $\mathrm{C} 57 \mathrm{Bl} / 6 \mathrm{~J}$ mice (wt/wt) transmitted the mutant allele to the next generation. Heterozygous mutant [GluR5(wt/R $\left.{ }^{\text {loxP }}\right)$; GluR5(wt/wt $\left.{ }^{\text {loxP }}\right)$ ], homozygous mutant [GluR5( $\left.\mathrm{R}^{\operatorname{loxP}} / \mathrm{R}^{\text {loxP }}\right)$ ], and control [GluR5$\left.\left(\mathrm{wt}^{\text {loxP}} / \mathrm{wt}^{\text {loxP }}\right)\right]$ mice were viable. GluR5 $\left(\mathrm{R}^{\text {loxP }} / \mathrm{R}^{\text {loxP }}\right)$ mice did not differ obviously from GluR5 (wt ${ }^{\text {loxP}} / \mathrm{wt}^{\text {loxP }}$ ) mice in breeding and general health status, although GluR5( $\left.\mathrm{R}^{\text {loxP}} / \mathrm{R}^{\text {loxP }}\right)$ mice had statistically lower body weight than did GluR5(wt ${ }^{\text {loxP }} / \mathrm{wt}^{\text {loxP }}$ ) mice $[28.7 \pm 0.5 \mathrm{gm}(n=27)$ vs $31.9 \pm 0.7 \mathrm{gm}(n=20) ; p<0.001$, ANOVA].

\section{Molecular analysis of mutant mice}

Southern analysis of genomic DNA digested with SpeI or EcoRI from the mutant mice confirmed homologous recombination of the targeting vectors and successful excision of the neomycin resistance marker, respectively. As predicted from the gene map, SpeI-digested genomic DNA showed a $15 \mathrm{~kb}$ fragment in GluR5( $\left.\mathrm{R}^{\text {loxP}} / \mathrm{R}^{\text {loxP }}\right)$ and GluR5(wt $\left.{ }^{\text {loxP }} / \mathrm{wt}^{\text {loxP }}\right)$ mice when hybridized with probe $A$ (see Fig. $1 A$ ), compared with $17.4 \mathrm{~kb}$ in 


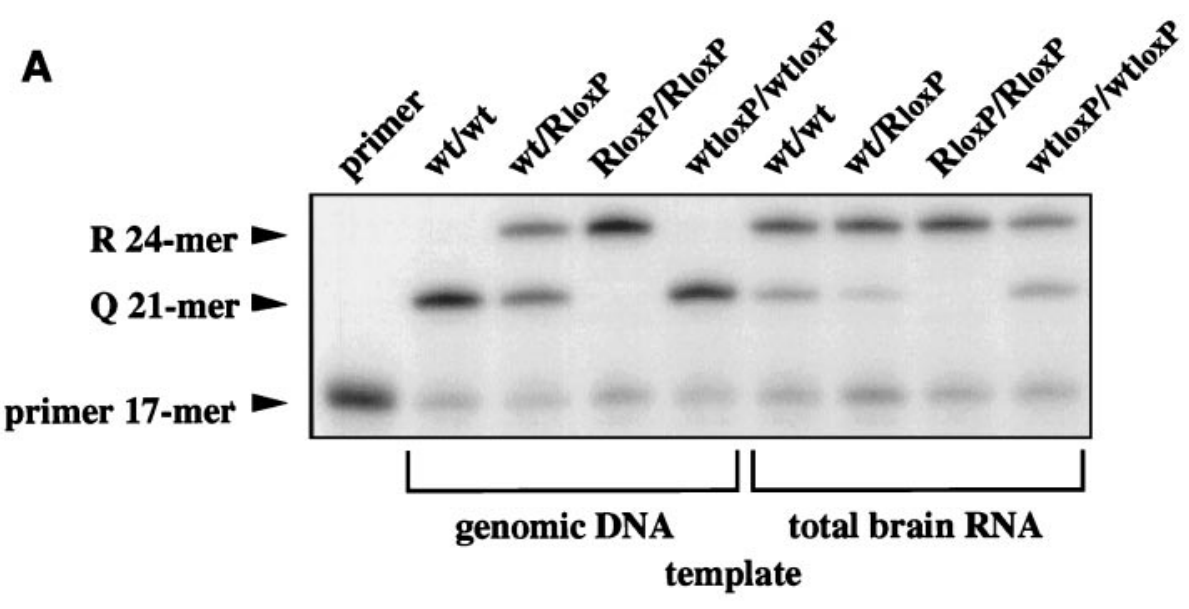

Figure 2. Analysis of GluR5 Q/R siteediting status and in situ hybridization of GluR5 mRNA. A, Analysis of the editing status of the GluR5 gene and GluR5 transcripts by an editing assay primer extension reaction. The region around the $\mathrm{Q} / \mathrm{R}$ site is amplified in a PCR (starting from mouse genomic tail DNA) or a reverse transcription-PCR (starting from total brain RNA); fragments are isolated and used as template in an editing assay (see Materials and Methods). B, In situ hybridization of parasagittal sections using ${ }^{33} \mathrm{P}$-labeled specific RNA probes for murine GluR5 mRNA.

\section{B}

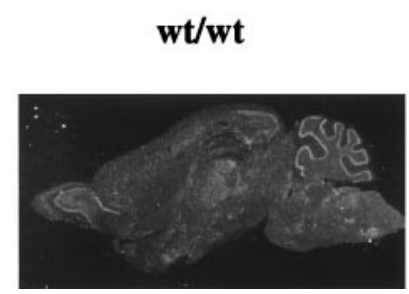

RloxP/RloxP

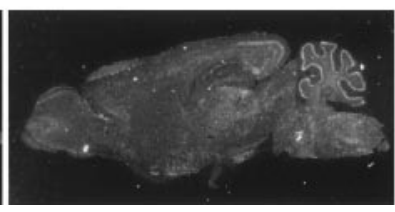

wtloxP/wtloxP

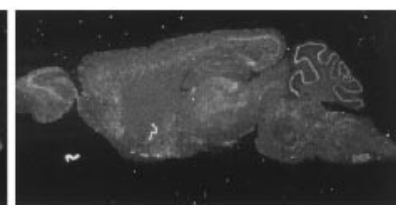

wild-type mice (Fig. 1D). Similarly, hybridization of EcoRIdigested DNA with probe $B$ (Fig. $1 A$ ) gave a fragment of $3.7 \mathrm{~kb}$ in the mutant mice, compared with $1.2 \mathrm{~kb}$ in the wild-type mice (Fig. 1E).

The presence of the point mutation at the $Q / R$ site of the GluR5 gene was verified by PCR amplification of this region from a genomic DNA template and subsequent analysis of the amplified product in an editing assay (Fig. $2 A$; see Materials and Methods) (H. H. Schiffer and S. F. Heinemann, unpublished observations). In this assay, a $17-\mathrm{mer}{ }^{32} \mathrm{P}$-labeled primer complementary to sequence upstream of the $\mathrm{Q} / \mathrm{R}$ site was extended in the presence of ddATP. Incorporation of ddATP terminated the primer extension at the $\mathrm{Q} / \mathrm{R}$ site if the codon was in the unedited (CAG) form (yielding a 21-mer product). In contrast, primer extension on edited templates incorporates dGTP at the editing site and continues the extension reaction to the next adenosine nucleotide, resulting in a 24-mer product. As predicted, analysis of the mouse tail genomic DNA showed that GluR5(wt/wt) and GluR5(wt ${ }^{\text {loxP }} / \mathrm{wt}^{\text {loxP }}$ ) animals contained only the CAG codon, whereas in GluR5( $\left.\mathrm{R}^{\text {loxP }} / \mathrm{R}^{\text {loxP }}\right)$ mice both GluR5 alleles had been altered to the CGG form (Fig. $2 A$ ).

The editing assay was also used to analyze the $\mathrm{Q} / \mathrm{R}$ siteediting status of mRNA transcripts from mutant and control mice (Fig. 2A). GluR5 cDNA transcribed from total brain RNA was PCR amplified, and fragments isolated from the region around the Q/R-editing site were analyzed. We found that wild-type and control animals partially edit GluR5 RNA at the Q/R site [GluR5(wt/wt), $68.5 \pm 0.5 \%$; GluR5(wt (oxP $\left.^{\text {lowt }}{ }^{\text {loxP }}\right), 61.9 \pm$ $0.5 \%$. As expected, heterozygotes showed a higher degree of editing [GluR5( $\left.\mathrm{R}^{\text {loxP}} / \mathrm{wt}\right), 82.4 \pm 0.2 \%$ ], and homozygous GluR5 $\left(\mathrm{R}^{\text {loxP}} / \mathrm{R}^{\text {loxP }}\right)$ mice exclusively expressed arginineencoding transcripts (Fig. $2 A$ ).

In situ hybridization analysis using radiolabeled probes did not reveal differences in GluR5 mRNA expression levels in brains from GluR5( $\left.{ }^{\text {loxP }} / \mathrm{R}^{\text {loxP }}\right)$, GluR5(wt $\left.{ }^{\text {loxP}} / \mathrm{wt}^{\text {loxP }}\right)$, and GluR5(wt/ wt) mice (Fig. 2B). Also, the pattern of expression of GluR5 mRNA, for example, in the Purkinje cell layer of the cerebellum and the hippocampus CA1 subfield, was not grossly altered in the mutant mice. Because of the qualitatively similar mRNA expression levels and pattern, it seems likely that the protein levels in mutant and control mice are comparable; however, we were not able to address this question directly by immunoblotting because of the unavailability of GluR5 subunit-specific antibodies.

Visual inspection of Nissl-stained brain sections did not reveal alterations in the gross morphology of major brain structures in mutant and control animals. On the basis of the dynamic expression profile of GluR5 mRNA during the development of the somatosensory cortex, it was suggested that GluR5 might have a special role in the formation of the "barrels" (Bahn et al., 1994), which are the somatotopic representation of the sensory vibrissae in rodents (Woolsey and Van der Loos, 1970). Using zinc and cytochrome oxidase histochemistry, we analyzed the barrel field in the somatosensory cortex of mutant and control animals but did not find significant alterations in the number or arrangement of the barrel columns (Fig. 3).

\section{Behavioral analysis of mutant mice}

The editing mutant mice were evaluated for their general neurological function and their motor- and spatial-learning behavior. GluR5( $\left.\mathrm{R}^{\text {loxP}} / \mathrm{R}^{\text {loxP }}\right)$ mice were indistinguishable from their wildtype counterparts in locomotor activity and in several sensorimotor tests including walk initiation, limb posture, visual placement, bridge crossing, negative geotaxis test, and muscle strength (data not shown). In the rotarod test, wild-type and mutant mice showed motor learning as judged by increased latencies to fall from the rotating rod ( 3 trials/d; $3 \mathrm{~d} ; p<0.0001$ ), but no difference between the two groups was detected. In a Morris water maze test ( 4 trials/d; $7 \mathrm{~d}$ ), control and mutant mice both showed learning as judged by changes in the distance and search time to find a hidden platform: distance in GluR5( $\left.\mathrm{wt}^{\text {loxP }} / \mathrm{wt}^{\text {loxP }}\right)$ was 


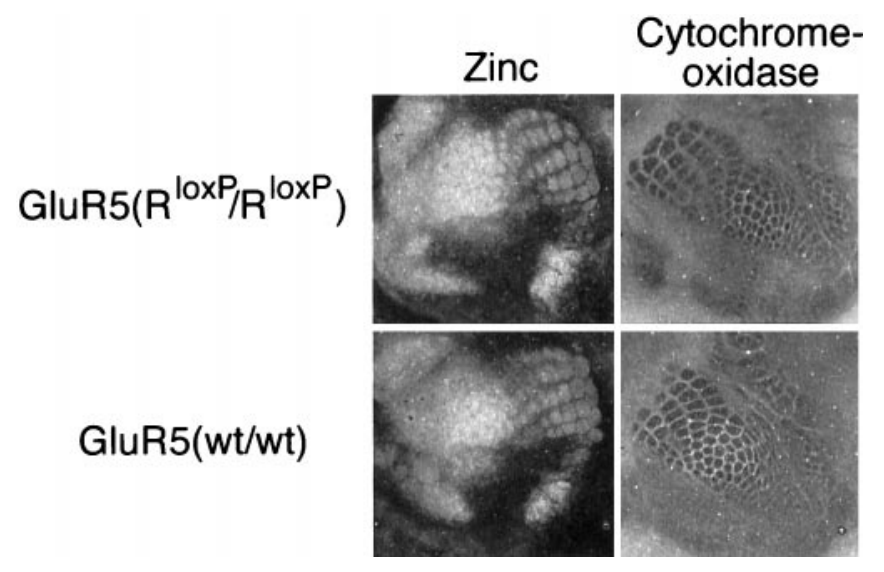

Figure 3. Analysis of the barrel fields in the somatosensory cortex of GluR5( $\left.\mathrm{R}^{\text {loxP}} / \mathrm{R}^{\text {loxP }}\right)$ and GluR5(wt/wt) mice reveals a normal barrel field pattern using either zinc or cytochrome oxidase histochemistry.

$596 \pm 25 \mathrm{~cm}$ on day 1 versus $333 \pm 71 \mathrm{~cm}$ on day 7 and in GluR5 $\left(\mathrm{R}^{\text {loxP }} / \mathrm{R}^{\text {loxP }}\right)$ was $567 \pm 18 \mathrm{~cm}$ on day 1 versus $321 \pm 24$ $\mathrm{cm}$ on day $7(n=20$ and 27 , respectively); latency in GluR5 $\left(\mathrm{wt}^{\mathrm{loxP}} / \mathrm{wt}^{\operatorname{loxP}}\right)$ was $35.0 \pm 1.3 \mathrm{sec}$ on day 1 versus $22.8 \pm$ $1.9 \mathrm{sec}$ on day 7 and in GluR5 $\left(\mathrm{R}^{\text {loxP}} / \mathrm{R}^{\text {loxP }}\right)$ was $35.8 \pm 1.0 \mathrm{sec}$ on day 1 versus $24.8 \pm 2.2 \mathrm{sec}$ on day $7(n=20$ and 27 , respectively; $p<0.0001)$. For both GluR5(wt $\left.{ }^{\operatorname{loxP}} / \mathrm{wt}^{\operatorname{loxP}}\right)$ and GluR5(R $\mathrm{R}^{\operatorname{loxP}} /$ $\left.\mathrm{R}^{\text {loxP }}\right)$ mice, the distance and latency on the ninth day compared with that on the first day were significantly lower $(p<0.0001)$, but there was no significant difference between the two strains of mice in terms of the degree of learning demonstrated in this test. In a subsequent probe trial with the platform removed, the animals showed a bias toward entering the quadrant that contained previously the hidden platform [percent of total entrances that were to the target quadrant, in GluR5( $\left.\mathrm{wt}^{\text {loxP }} / \mathrm{wt}^{\text {loxP }}\right), 35.7 \%$ $\pm 2.1 \%(n=20)$; in GluR5( $\left.\mathrm{R}^{\operatorname{loxP}} / \mathrm{R}^{\text {loxP }}\right), 29.5 \% \pm 3.2 \%(n=$ 27)], demonstrating that the mice focused their search in the trained area.

\section{Kainate-induced seizure}

Administration of kainic acid in rodents results in a wellcharacterized seizure syndrome that is associated with excitotoxic neurodegeneration in selected populations of neurons located in the hippocampus (Nadler, 1981; Ben-Ari, 1985). Mulle et al. (1998) showed that mouse mutants deficient for the GluR6 receptor subunit have a reduced susceptibility to kainate-induced seizure, demonstrating that kainate receptor containing this subunit in part mediates this excitotoxic phenomenon. We therefore examined whether the alteration in the editing status of the GluR5 subunit altered the seizure susceptibility. Kainate was administered intraperitoneally at $20 \mathrm{mg} / \mathrm{kg}$ to control and editing mutant animals. The latency to seizure onset and the number and severity of seizures were recorded for $2 \mathrm{hr}$ after injection. From these data, a seizure index (SI) was calculated (see Materials and Methods). We found that GluR5( $\left.\mathrm{R}^{\text {loxP}} / \mathrm{R}^{\text {loxP }}\right)$ mice did not show a difference in their latency to seizure onset and their seizure index compared with that of either wild-type or GluR5(wt ${ }^{\operatorname{loxP}} /$ $\left.\mathrm{wt}^{\text {loxP }}\right)$ mice. In GluR5( $\left.\mathrm{R}^{\text {loxP }} / \mathrm{R}^{\text {loxP }}\right)$ mice, 9 of 15 had seizures, with a mean latency of $23.4 \pm 2.2 \mathrm{~min}$ and an SI of $1.5 \pm 0.5$. All 12 GluR5(wt ${ }^{\text {loxP }} / \mathrm{wt}^{\text {loxP }}$ ) had seizures; the mean latency and SI were $24.0 \pm 3.9 \mathrm{~min}$ and $2.1 \pm 0.3$, respectively. Finally, kainate induced seizures in 7 of 10 GluR5(wt/wt) mice; the seizures had a mean latency of $21.9 \pm 4.7 \mathrm{~min}$ and an SI of $1.9 \pm 0.5$.
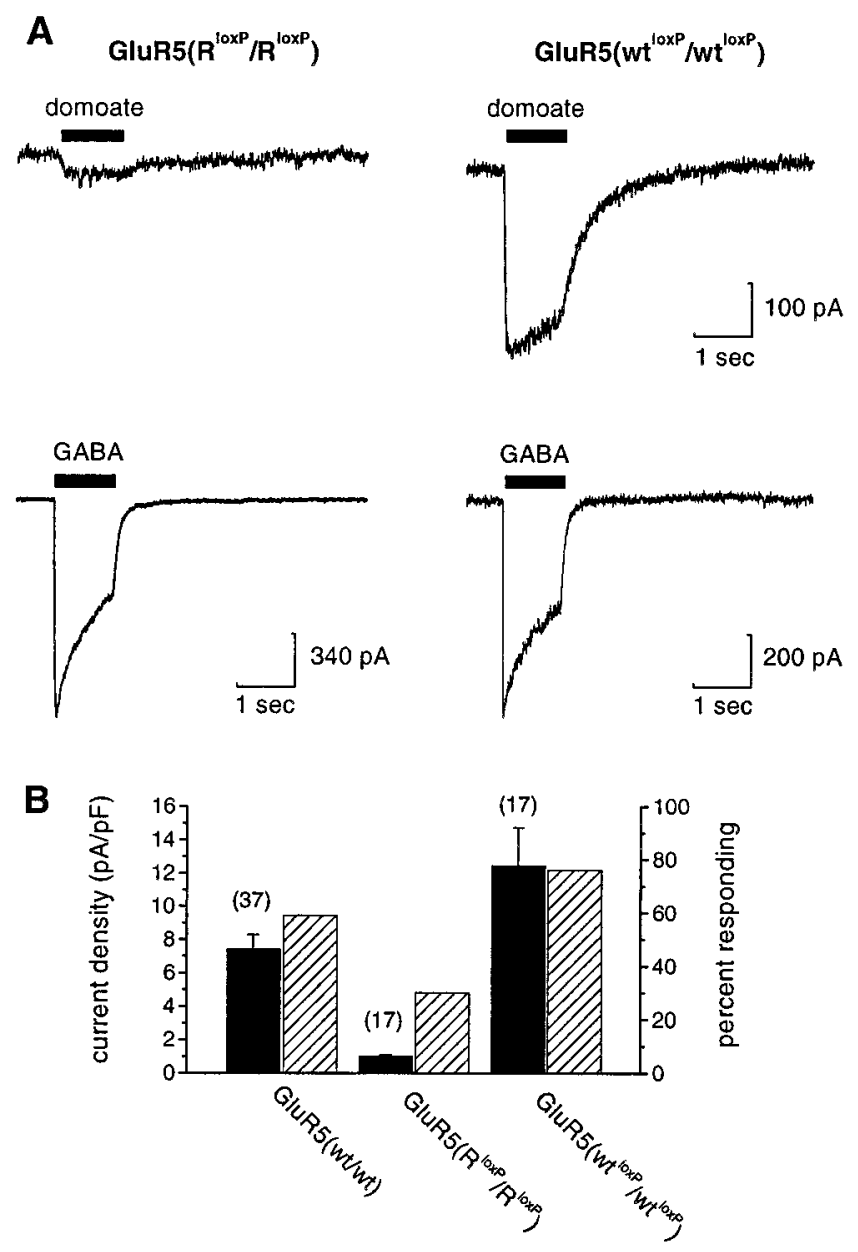

Figure 4. Kainate receptor currents are reduced in the GluR5(R ${ }^{\operatorname{loxP}} /$ $\mathrm{R}^{\text {loxP }}$ ) mice compared with those in GluR5(wt $\left.\mathrm{w}^{\text {loxP }} / \mathrm{wt}^{\text {loxP }}\right)$ and wild-type mice. $A$, Representative whole-cell kainate receptor (top) and GABA receptor (bottom) currents evoked by application (solid horizontal bar) of $10 \mu \mathrm{M}$ domoate or $1 \mathrm{mM}$ GABA to acutely isolated dorsal root ganglia neurons from GluR5( $\left.\mathrm{R}^{\text {loxP}} / \mathrm{R}^{\text {loxP }}\right)$ (left) and GluR5(wt $\left.{ }^{\text {loxP }} / \mathrm{wt}^{\text {loxP }}\right)$ (right) mice. Applications were for $1 \mathrm{sec}$. Neurons were held at $-70 \mathrm{mV}$. B, Mean DRG neuronal kainate receptor current densities (black columns; left $y$-axis) and percentages of neurons that exhibited kainate receptor currents (hatched columns; right y-axis) shown for the three strains of mice. The number of responding cells is given above each black column. Current densities were calculated by normalizing the amplitude of the kainate receptor current at $-70 \mathrm{mV}$ to the cell capacitance.

\section{Electrophysiology of kainate receptor responses in DRG neurons}

To assay for a physiological phenotype in the editing mutant mice, we performed whole-cell recordings on small-diameter dorsal root ganglion neurons, whose kainate receptor responses arise predominantly from GluR5-containing receptors (Huettner, 1990; Sommer et al., 1992; Partin et al., 1993; Swanson and Heinemann, 1998). DRG neurons isolated from mutant mice showed no apparent differences in viability, and those with kainate receptor responses had the same membrane capacitance $(\mathrm{Cm})$ as wild-type neurons: GluR5( $\left.\mathrm{R}^{\text {loxP }} / \mathrm{R}^{\text {loxP }}\right) \mathrm{Cm}=21.0 \pm 2.0$ $\mathrm{pF}(n=17) ; \operatorname{GluR} 5\left(\mathrm{wt}^{\text {loxP}} / \mathrm{wt}^{\text {loxP }}\right) \mathrm{Cm}=17.9 \pm 1.2 \mathrm{pF}(n=16)$; and GluR5(wt/wt) $\mathrm{Cm}=17.8 \pm 0.7 \mathrm{pF}(n=37)$. Domoate $(10$ $\mu \mathrm{M})$, a high-affinity agonist of DRG kainate receptors, was used to evoke currents in acutely dissociated sensory neurons from mice at ages P1-P8 (see examples in Fig. 4A). Current amplitudes 
were normalized against cell capacitance to determine current density in the neurons. We found that fewer DRG neurons gave detectable responses to domoate application: $30 \%$ of neurons from GluR5( $\mathrm{R}^{\text {loxP }} / \mathrm{R}^{\text {loxP }}$ ) mice responded versus 76 and $59 \%$ of neurons from GluR5(wt ${ }^{\text {loxP }} / \mathrm{wt}^{\text {loxP }}$ ) and GluR5(wt/wt) mice, respectively ( $n=57,21$, and 63 , respectively). The current density in GluR5( $\left.\mathrm{R}^{\text {loxP }} / \mathrm{R}^{\text {loxP }}\right)$ neurons $[1.0 \pm 0.1 \mathrm{pA} / \mathrm{pF}(n=17)]$ was also significantly smaller than that in GluR5(wt $\left.{ }^{\text {loxP }} / \mathrm{wt}^{\text {loxP }}\right)$ neurons $[12.4 \pm 2.3 \mathrm{pA} / \mathrm{pF}(n=17)]$ and GluR5(wt/wt) neurons $[7.4 \pm 0.9 \mathrm{pA} / \mathrm{pF}(n=37)](p<0.01)$ (Fig. $4 B)$. The currents evoked by domoate in DRG neurons from the editing mutant mice showed kinetics similar to that in neurons from control mice. Also, all DRG neurons tested from the mutant mice had robust GABA receptor currents similar in amplitude to those observed in wild-type neurons (Fig. $4 A$ ), suggesting that alteration in the GluR5 receptor subunit did not impact other receptor systems in these neurons.

\section{Pain behavior in wild-type and mutant animals}

Because of their prominent expression in dorsal root ganglia neurons (Partin et al., 1993) and on the basis of effects of receptor antagonists on pain behavior (Sang et al., 1998; Simmons et al., 1998), GluR5-containing kainate receptors have been suggested to play an as-yet undefined role in mediating pain transmission. We tested the editing mutant mice for alterations in their behavioral responses to noxious thermal and chemical stimuli. First, we analyzed acute thermal nociception by placing mice on a $52.5^{\circ} \mathrm{C}$ heat block and measuring the time until vocalization or jumping occurred. We found no significant difference in the latency times to react to this thermal stimulus between mutant and control animals [GluR5( $\left.\mathrm{R}^{\text {loxP }} / \mathrm{R}^{\text {loxP }}\right), 21.6 \pm 0.9$ sec $(n=38)$; GluR5(wt $\left.\left.\mathrm{woxP}^{\text {lowt }} \mathrm{wt}^{\text {loxP }}\right), 21.1 \pm 0.7 \mathrm{sec}(n=43) ; p=0.69\right]$. We also tested an animal model of persistent nociceptive activation, in which formalin was injected into the hindpaw of the mice. Formalin injection activates sensory afferents, leading to pain behaviors such as licking and flinching. A 5\% formalin solution was injected subcutaneously into the hindpaw of mutant and wildtype animals, and licking and flinching behavior was recorded for the following $45 \mathrm{~min}$ (Fig. 5). We did not find a significant difference in the total paw-licking time in response to formalin injection, in either the early or late phases of the $45 \mathrm{~min}$ response profile, between mutant and control animals [early/late phase; $\operatorname{GluR5}\left(\mathrm{R}^{\operatorname{loxP}} / \mathrm{R}^{\text {loxP}}\right), 175 \pm 16 \mathrm{sec} / 370 \pm 33 \mathrm{sec}(n=10)$; GluR5( $\left.\left.\mathrm{wt}^{\text {loxP }} / \mathrm{wt}^{\text {loxP }}\right), 163 \pm 13 \mathrm{sec} / 432 \pm 35 \mathrm{sec}(n=10)\right]$.

\section{DISCUSSION}

RNA editing of mammalian ionotropic glutamate receptor subunits is a tightly controlled mechanism that can change the functional properties of the receptor channels. Although much is known about the functional consequences of editing from work with recombinant receptor subunits, the importance of this developmentally regulated process in vivo remains unclear, particularly for the kainate receptor subunits GluR5 and GluR6. We chose to address this issue using transgenic techniques to generate a mouse that expresses a GluR5 subunit containing an arginine at the Q/R-editing site. A similar strategy was used recently to assess the role of the small amount of unedited GluR2 subunit mRNA present early in development (Kask et al., 1998). The technique we used to generate the GluR5 $\left(\mathrm{R}^{\operatorname{loxP}} / \mathrm{R}^{\text {loxP }}\right)$ mouse leaves a small DNA insertion, a loxP site, in the GluR5 gene intron downstream of the MD2 exon. Because insertion of the neomycin resistance marker into the intronic sequence of a target
A

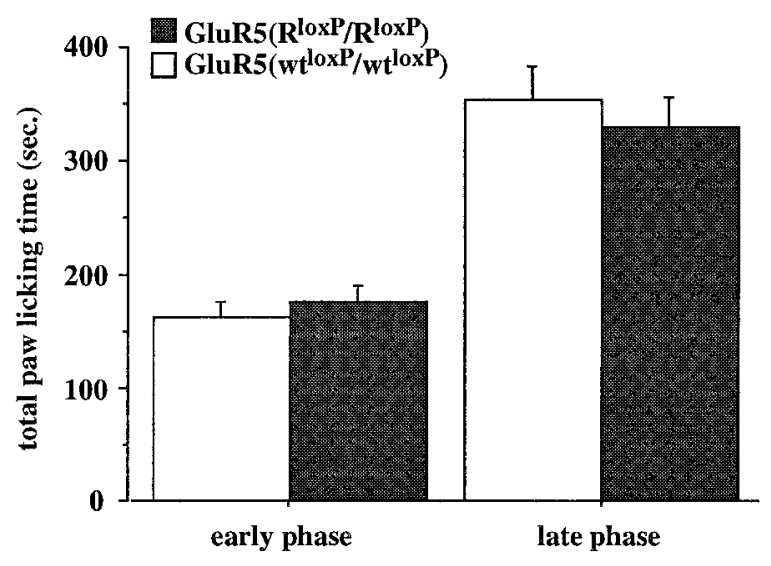

B

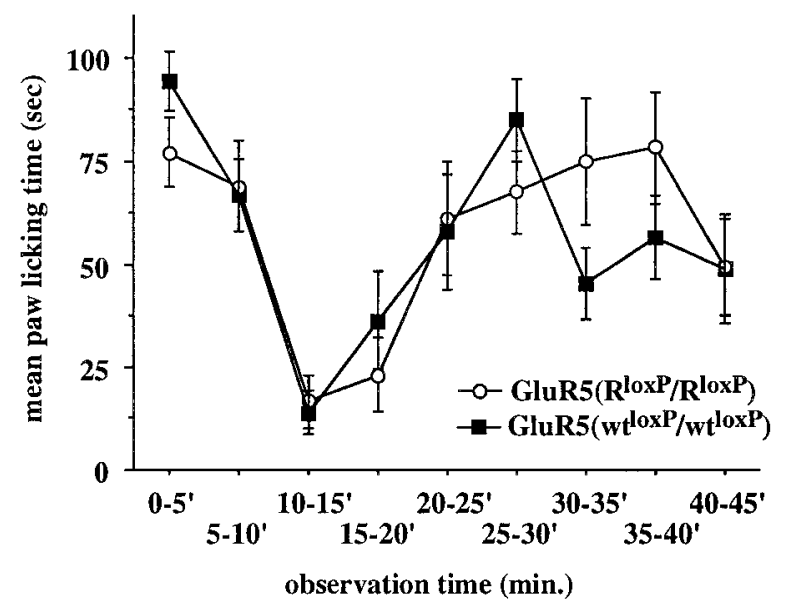

Figure 5. Analysis of formalin-induced paw-licking behavior in GluR5(R $\left.{ }^{\text {loxP }} / \mathrm{R}^{\text {loxP }}\right)$ and GluR5(wt $\left.{ }^{\text {loxP }} / \mathrm{wt}^{\text {loxP }}\right)$ animals. The number of licking events after injection of formalin was recorded in 5 min time bins. $A$, Cumulative total paw-licking time (seconds) for the early ( $0-15 \mathrm{~min})$ and the late (15-45 min) phases (mean \pm SEM). $B$, Paw-licking time after formalin injection for each 5 min time bin (mean \pm SEM) for a total of $45 \mathrm{~min}$.

gene has been shown to affect transcription (e.g., Brusa et al., 1995), we generated a control mouse using a similar strategy, with the exception that the targeting vector contained the wild-type glutamine codon at the $\mathrm{Q} / \mathrm{R}$ site. In this report we have tested neuronal systems in which GluR5 has been shown, or is predicted, to play a role. For this reason, we examined pain perception and dorsal root ganglia neuron kainate receptor responses, spatial and motor learning, barrel formation in the sensorimotor cortex, and susceptibility to kainate-induced seizures.

One striking point that comes out of our analysis of these mice is that they show no obvious developmental abnormalities, despite the well documented developmental regulation of GluR5 Q/R site editing. In embryonic rat brain as little as $6 \%$ of the GluR5 mRNA transcripts are edited at the $\mathrm{Q} / \mathrm{R}$ site. In adult brain this percentage varies between 40 and $80 \%$ (Bernard and Khrestchatisky, 1994; Paschen and Djuricic, 1994; Paschen et al., 1995). In addition, a dramatic increase in $\mathrm{Q} / \mathrm{R}$ site editing for the GluR5 subunit occurs during terminal differentiation of the human teratocarcinoma cell line NT2 (Lai et al., 1997). These observed patterns of editing, associated with the reduction in calcium 
permeability of the receptor channels that results from $Q / R$ site editing, have led to the hypothesis that the editing process may play an important role in the maturation of neurons or the formation of excitatory synapses (Paschen et al., 1995). One brain region that we thought might show anatomical abnormalities resulting from the mutation in the GluR5 subunit was the sensorimotor barrel cortex, a developmentally plastic cortical field in which GluR5 mRNA is highly expressed around birth but not at all in the adult rat (Bahn et al., 1994). Furthermore, chronic blockade of ionotropic glutamatergic receptors immediately after birth interferes with barrel formation in the developing rat (Schlaggar et al., 1993), and genetic experiments have demonstrated a clear involvement of NMDA receptors in barrel formation (e.g., Iwasato et al., 1997). However, we did not find significant alterations in the barrel pattern in $\mathrm{GluR} 5\left(\mathrm{R}^{\operatorname{loxP}} / \mathrm{R}^{\text {loxP }}\right)$ mice. These results suggest that changes in the GluR5-editing status and consequently the calcium permeability of kainate receptors formed from these subunits are not used to shape neuronal architecture during development, at least in the barrel field.

GluR5( $\left.\mathrm{R}^{\text {loxP}} / \mathrm{R}^{\text {loxP }}\right)$ mutant mice formed spatial memories with similar facility and were as susceptible to kainate-induced seizures as were wild-type and control mutant mice. This was surprising, because GluR5-containing kainate receptors in the hippocampus have been shown to modulate inhibitory transmission in the CA1 region, although the end result of kainate receptor activation remains the subject of some debate (Clarke et al., 1997; Rodriguez-Moreno et al., 1997; Cossart et al., 1998; Frerking et al., 1998; Mulle et al., 1998). On the basis of some of these results, it has been suggested that GluR5-containing kainate receptors play a role in either facilitating (Clarke et al., 1997) or inhibiting (Cossart et al., 1998) convulsant behavior, particularly when induced by kainate injection, which has been used as a model for temporal lobe epilepsy (Ben-Ari, 1985). We predict that the gain of kainate receptor modulation of inhibitory transmission in the CA1 region will be significantly reduced in the GluR5( $\left.\mathrm{R}^{\text {loxP }} / \mathrm{R}^{\text {loxP }}\right)$-editing mutant mice, based on the known reduction in single-channel conductance exhibited by edited compared with unedited kainate receptors (Swanson et al., 1996). The absence of an increased sensitivity to kainate-induced seizure in these mice therefore supports a modulatory, not primary, role for CA1 interneuron kainate receptors in this model of epileptogenesis, which was suggested previously (Cossart et al., 1998). An interesting question that remains to be explored is whether GluR5-expressing CA1 interneurons in the stratum oriens, which have been shown to be particularly sensitive to pilocarpineinduced apoptosis (Houser and Esclapez, 1996; Cossart et al., 1998), are more resistant to excitotoxic insult in the editing mutant mice.

It has been proposed that GluR5-containing receptors are involved in the transmission of nociceptive information in the peripheral nervous system. This hypothesis arises from several lines of investigation. First, a subpopulation of small-diameter dorsal root ganglia neurons contain glutamate receptor currents that seem to arise from GluR5 subunit-containing receptors (Huettner, 1990; Sommer et al., 1992; Partin et al., 1993; Swanson et al., 1996). Second, pharmacological blockade of GluR5containing receptors with receptor antagonists significantly reduced the behavioral response to the chemical irritant formalin in rats (Simmons et al., 1998). More recently, synaptic kainate receptor currents were characterized in a population of dorsal horn neurons that likely received nociceptive input ( $\mathrm{Li}$ et al., 1999). These data led us to compare nociceptive responses in the
GluR5( $\left.\mathrm{R}^{\text {loxP}} / \mathrm{R}^{\text {loxP }}\right)$ and GluR5(wt $\left.\mathrm{w}^{\text {loxP }} / \mathrm{wt}^{\text {loxP }}\right)$ mice. We found that although kainate receptor currents in acutely isolated DRG neurons were greatly reduced, no significant differences either in acute thermal nociception or in the formalin test were detected in the mice. These results support the interpretation that GluR5 subunit-containing receptors are the principal mediator of the glutamate receptor response in dorsal root ganglion neurons. However, the behavioral results do not provide evidence of the hypothesis that these receptors have a central role in mediation of pain perception, at least in the behavioral models we tested. These results are apparently at odds with those of Simmons et al. (1998), but a number of potential explanations for the discrepancy can be postulated. These include the use of different species of animal (rats vs mice) or the possibility that the antagonist used in the previous study does not discriminate between receptor types with the same degree of selectivity for native and recombinant kainate receptors (Simmons et al., 1998). Finally, one unavoidable complication inherent to unregulated gene-targeting experiments is the possibility that the genetic alterations might engender compensatory mechanisms during development. However, it is unlikely that functional replacement of the GluR5dependent response in DRG neurons occurred, because we observed the decrease in current density in the GluR5( $\left.\mathrm{R}^{\operatorname{lox} P} / \mathrm{R}^{\text {loxP }}\right)$ editing mutant mice predicted by the differences in single-channel conductances of edited and unedited GluR5 kainate receptors (Swanson et al., 1996).

Our results demonstrate that $\mathrm{Q} / \mathrm{R}$ editing of the GluR5 subunit is not important for the short- or long-term viability of mice, the gross anatomical development of the brain, spatial learning, or nociceptive transmission. The latter is perhaps the most surprising result, given the evidence of participation of the GluR5 subunit-containing receptor in pain transmission. The observation that none of the systems that we examined were altered in the GluR5( $\left.\mathrm{R}^{\text {loxP}} / \mathrm{R}^{\text {loxP }}\right)$ mice is a result qualitatively similar to that reported for GluR-B ${ }^{\mathrm{R} / \mathrm{R}}$ mice generated by Kask et al. (1998). Despite the absence of an obvious behavioral phenotype in our initial study, however, these mice represent valuable genetic tools for characterizing the growing number of neuronal kainate receptors and the physiological and pathological process they may mediate.

\section{REFERENCES}

Bahn S, Volk B, Wisden W (1994) Kainate receptor gene expression in the developing rat brain. J Neurosci 14:5525-5547.

Ben-Ari Y (1985) Limbic seizure and brain damage produced by kainic acid: mechanisms and relevance to human temporal lobe epilepsy. Neuroscience 14:375-403.

Bernard A, Khrestchatisky M (1994) Assessing the extent of RNA editing in the TMII regions of GluR5 and GluR6 kainate receptors during rat brain development. J Neurochem 62:2057-2060.

Bernard A, Ferhat L, Dessi F, Charton G, Represa A, Ben-Ari Y, Khrestchatisky M (1999) Q/R editing of the rat GluR5 and GluR6 kainate receptors in vivo and in vitro: evidence for independent developmental, pathological and cellular regulation. Eur J Neurosci 11:604-616.

Bischoff S, Barhanin J, Bettler B, Mulle C, Heinemann S (1997) Spatial distribution of kainate receptor subunit mRNA in the mouse basal ganglia and ventral mesencephalon. J Comp Neurol 379:541-562.

Bleakman R, Schoepp DD, Ballyk B, Bufton H, Sharpe EF, Thomas K, Ornstein PL, Kamboj RK (1996) Pharmacological discrimination of GluR5 and GluR6 kainate receptor subtypes by $(3 S, 4 \mathrm{a} R, 6 R, 8 \mathrm{a} R)-6-[2-$ (1(2)H-tetrazole-5-yl)ethyl]decahyd roisdoquinoline-3 carboxylic-acid. Mol Pharmacol 49:581-585.

Boulter J, Hollmann M, O’Shea-Greenfield A, Hartley M, Deneris E, Maron C, Heinemann S (1990) Molecular cloning and functional expression of glutamate receptor subunit genes. Science 249:1033-1037. 
Brusa R, Zimmermann F, Koh DS, Feldmeyer D, Gass P, Seeburg PH, Sprengel R (1995) Early-onset epilepsy and postnatal lethality associated with an editing-deficient GluR-B allele in mice. Science 270:1677-1680.

Castillo PE, Malenka RC, Nicoll RA (1997) Kainate receptors mediate a slow postsynaptic current in hippocampal CA3 neurons. Nature 388:182-186.

Chomczynski P, Sacchi N (1987) Single-step method of RNA isolation by acid guanidinium thiocyanate-phenol-chloroform extraction. Anal Biochem 162:156-159.

Clarke VR, Ballyk BA, Hoo KH, Mandelzys A, Pellizzari A, Bath CP, Thomas J, Sharpe EF, Davies CH, Ornstein PL, Schoepp DD, Kamboj RK, Collingridge GL, Lodge D, Bleakman D (1997) A hippocampal GluR5 kainate receptor regulating inhibitory synaptic transmission. Nature 389:599-603.

Cossart R, Esclapez M, Hirsch JC, Bernard C, Ben-Ari Y (1998) GluR5 kainate receptor activation in interneurons increases tonic inhibition of pyramidal cells. Nat Neurosci 1:470-478.

Danscher G (1982) Exogenous selenium in the brain. A histochemical technique for light and electron microscopical localization of catalytic selenium bonds. Histochemistry 76:281-293.

Dingledine R, Borges K, Bowie D, Traynelis SF (1999) The glutamate receptor ion channels. Pharmacol Rev 51:7-62.

Dyck R, Beaulieu C, Cynader M (1993) Histochemical localization of synaptic zinc in the developing cat visual cortex. J Comp Neurol 329:53-67.

Egebjerg J, Heinemann SF (1993) $\mathrm{Ca}^{2+}$ permeability of unedited and edited versions of the kainate selective glutamate receptor GluR6. Proc Natl Acad Sci USA 90:755-759.

Frerking M, Malenka RC, Nicoll RA (1998) Synaptic activation of kainate receptors on hippocampal interneurons. Nat Neurosci 1:479-486.

Gaumann DM, Yaksh TL, Post C, Wilcox GL, Rodriguez M (1989) Intrathecal somatostatin in cat and mouse studies on pain, motor behavior, and histopathology. Anesth Analg 68:623-632.

Gregor P, O’Hara BF, Yang X, Uhl GR (1993) Expression and novel subunit isoforms of glutamate receptor genes GluR5 and GluR6. NeuroReport 4:1343-1346.

Hayes AG, Sheehan MJ, Tyers MB (1987) Differential sensitivity of models of antinociception in the rat, mouse and guinea-pig to mu- and kappa-opioid receptor agonists. Br J Pharmacol 91:823-832.

Higuchi M, Single FN, Köhler M, Sommer B, Sprengel R, Seeburg PH (1993) RNA editing of AMPA receptor subunit GluR-B: a base-paired intron-exon structure determines position and efficiency. Cell 75:1361-1370.

Houser CR, Esclapez M (1996) Vulnerability and plasticity of the GABA system in the pilocarpine model of spontaneous recurrent seizures. Epilepsy Res 26:207-218.

Huettner JE (1990) Glutamate receptor channels in rat DRG neurons: activation by kainate and quisqualate and blockade of desensitization by Con A. Neuron 5:255-266.

Hunskaar S, Fasmer OB, Hole K (1985) Formalin test in mice, a useful technique for evaluating mild analgesics. J Neurosci Methods 14:69-76.

Iwasato T, Erzurumlu RS, Huerta PT, Chen DF, Sasaoka T, Ulupinar E, Tonegawa S (1997) NMDA receptor-dependent refinement of somatotopic maps. Neuron 19:1201-1210.

Kask K, Zamanillo D, Rozov A, Burnashev N, Sprengel R, Seeburg PH (1998) The AMPA receptor subunit GluR-B in its Q/R site-unedited form is not essential for brain development and function. Proc Natl Acad Sci USA 95:13777-13782.

Keinänen K, Wisden W, Sommer B, Werner P, Herb A, Verdoorn TA, Sakmann B, Seeburg PH (1990) A family of AMPA-selective glutamate receptors. Science 249:556-560.

Kempermann G, Kuhn HG, Gage FH (1997) More hippocampal neurons in adult mice living in an enriched environment. Nature 386:493-495.

Köhler M, Burnashev N, Sakmann B, Seeburg PH (1993) Determinants of $\mathrm{Ca}^{2+}$ permeability in both TM1 and TM2 of high affinity kainate receptor channels: diversity by RNA editing. Neuron 10:491-500.

Lai F, Chen CX, Lee VM, Nishikura K (1997) Dramatic increase of the RNA editing for glutamate receptor subunits during terminal differentiation of clonal human neurons. J Neurochem 69:43-52.

Laird PW, Zijderveld A, Linders K, Rudnicki MA, Jaenisch R, Berns A (1991) Simplified mammalian DNA isolation procedure. Nucleic Acids Res 19:4293.

Li P, Wilding TJ, Kim SJ, Calejesan AA, Huettner JE, Zhuo M (1999)
Kainate-receptor-mediated sensory synaptic transmission in mammalian spinal cord. Nature 397:161-164.

Mansour SL, Thomas KR, Capecchi MR (1988) Disruption of the proto-oncogene int-2 in mouse embryo-derived stem cells: a general strategy for targeting mutations to non-selectable genes. Nature 336:348-352.

Mulle C, Sailer A, Pérez-Otaño I, Dickinson-Anson H, Castillo PE, Bureau I, Maron C, Gage FH, Mann JR, Bettler B, Heinemann SF (1998) Altered synaptic physiology and reduced susceptibility to kainate-induced seizures in GluR6-deficient mice. Nature 392:601-605.

Nadler JV (1981) Minireview. Kainic acid as a tool for the study of temporal lobe epilepsy. Life Sci 29:2031-2042.

Nakanishi N, Shneider NA, Axel R (1990) A family of glutamate receptor genes: evidence for the formation of heteromultimeric receptors with distinct channel properties. Neuron 5:569-581.

O'Gorman S, Dagenais NA, Qian M, Marchuk Y (1997) Protamine-Cre recombinase transgenes efficiently recombine target sequences in the male germ line of mice, but not in embryonic stem cells. Proc Natl Acad Sci USA 94:14602-14607.

Partin KM, Patneau DK, Winters CA, Mayer ML, Buonanno A (1993) Selective modulation of desensitization at AMPA versus kainate receptors by cyclothiazide and concanavalin A. Neuron 11:1069-1082.

Paschen W, Djuricic B (1994) Extent of RNA editing of glutamate receptor subunit GluR5 in different brain regions of the rat. Cell Mol Neurobiol 14:259-270.

Paschen W, Schmitt J, Dux E, Djuricic B (1995) Temporal analysis of the upregulation of GluR5 mRNA editing with age: regional evaluation. Brain Res Dev Brain Res 86:359-363.

Paternain AV, Morales M, Lerma J (1995) Selective antagonism of AMPA receptors unmasks kainate receptor-mediated responses in hippocampal neurons. Neuron 14:185-189.

Robertson E, Bradley A, Kuehn M, Evans M (1986) Germ-line transmission of genes introduced into cultured pluripotential cells by retroviral vector. Nature 323:445-448.

Robertson EJ (1987) Embryo-derived stem cell lines. In: Teratocarcinomas and embryonic stem cells: a practical approach (Robertson EJ, ed), pp 71-112. Oxford: IRL.

Rodriguez-Moreno A, Herreras O, Lerma J (1997) Kainate receptors presynaptically downregulate GABAergic inhibition in the rat hippocampus. Neuron 19:893-901.

Sang CN, Hostetter MP, Gracely RH, Chappell AS, Schoepp DD, Lee G, Whitcup S, Caruso R, Max MB (1998) AMPA/kainate antagonist LY293558 reduces capsaicin-evoked hyperalgesia but not pain in normal skin in humans. Anesthesiology 89:1060-1067.

Schlaggar BL, Fox K, O'Leary DD (1993) Postsynaptic control of plasticity in developing somatosensory cortex. Nature 364:623-626.

Silverman MS, Tootell RB (1987) Modified technique for cytochrome oxidase histochemistry: increased staining intensity and compatibility with 2-deoxyglucose autoradiography. J Neurosci Methods 19:1-10.

Simmons DM, Arriza JL, Swanson LW (1989) A complete protocol for in situ hybridization of messenger RNAs in brain and other tissues with radiolabeled single-stranded RNA probes. J Histotechnol 12:169-181.

Simmons RM, Li DL, Hoo KH, Deverill M, Ornstein PL, Iyengar S (1998) Kainate GluR5 receptor subtype mediates the nociceptive response to formalin in the rat. Neuropharmacology 37:25-36.

Sommer B, Köhler M, Sprengel R, Seeburg PH (1991) RNA editing in brain controls a determinant of ion flow in glutamate-gated channels. Cell 67:11-19.

Sommer B, Burnashev N, Verdoorn TA, Keinänen K, Sakmann B, Seeburg PH (1992) A glutamate receptor channel with high affinity for domoate and kainate. EMBO J 11:1651-1656.

Swanson GT, Heinemann SF (1998) Heterogeneity of homomeric GluR5 kainate receptor desensitization expressed in HEK293 cells. J Physiol (Lond) 513:639-646.

Swanson GT, Feldmeyer D, Kaneda M, Cull-Candy SG (1996) Effect of RNA editing and subunit co-assembly single-channel properties of recombinant kainate receptors. J Physiol (Lond) 492:129-142.

Vignes M, Collingridge GL (1997) The synaptic activation of kainate receptors. Nature 388:179-182.

Wilding TJ, Huettner JE (1997) Activation and desensitization of hippocampal kainate receptors. J Neurosci 17:2713-2721.

Woolsey TA, Van der Loos H (1970) The structural organization of layer IV in the somatosensory region (SI) of mouse cerebral cortex. The description of a cortical field composed of discrete cytoarchitectonic units. Brain Res 17:205-242. 